\title{
NOTES ON THE VARIATION OCCURRING IN TUBULARIA LARYNX ELLIS \& SOLANDER
}

\author{
By F. B. Hawes \\ R.O.S.C.M. Ltd., Laboratory, New Quay Road, Poole, Dorset
}

(Text-figs. I-5)

In the course of an investigation into the settlement of actinula larva of Tubularia larynx Ellis \& Solander, the variations in the material collected suggested that more than one species of Tubularia might be present at Plymouth. Pyefinch \& Downing (I949) had noted variations in the species occurring at Millport, but had decided that it could most satisfactorily be included in T. larynx.

Brink (I925a) drew attention to Fenchel (I905), who showed that twentytwo forms of Tubularia described as new species were T. larynx. Amongst these Fenchel included Hincks's (I868) T. coronata and Allman's (I87I) species spectabilis, pacifica, attenuata, polycarpa, tenella, bellis and humilis. These had been given status as species because insufficient notice had been given to the variability of the specific characters.

Errors have also been made because immature individuals have been described. Brink (I925b) concluded that the species Vorticlava (Alder) and Acharadria (Wright) (see Hincks, pp. 13I-4) are immature forms of Tubularia larynx.

A search through the literature has shown that many authors, including Stechow (I925a), Pérez (I925) and Vervoort (I946), have mentioned the instability of the 'specific' characters of T. larynx. Sometimes new species are described which are almost certainly $T$. larynx, such as $T$. sphaerogona Hargitt 1927, $T$. radiata Uchida 1936, and $T$. venusta Yamada 1950. Stechow (1925b) describes $T$. australis as synonymous with $T$. gracilis Harvey and $T$. gracilis Lendenfeld, but Fenchel considered both these two species to be synonymous with larynx. The descriptions given by other authors are often insufficient to distinguish the material from $T$. crocea or immature $T$. indivisa.

The aim in this paper is to illustrate the variations that occur in the specific characters of $T$. larynx (based on Allman's description) and, where possible, to explain them.

The work was undertaken in Plymouth in I952. I am grateful for the advice and help I received from the Director and Staff of the Laboratory. I wish to thank Dr W. J. Rees for the interest he has shown. I am further indebted to the Chairman and the Members of the R.O.S.C.M. Ltd. for permission to publish this work. 


\section{METHOD}

The material examined was collected from buoys in the Sound or taken from a raft moored near the Breakwater. On being brought into the laboratory, the clumps were washed to remove the tubes of fassa falcata. They were placed in glass bowls and the water was changed 3 or 4 times a day.

All attempts at culturing were unsuccessful.

The measurements of the heights of the stems are approximate-there is no morphological difference between the stem and the stolon. Measurements and counts were made with the aid of a dissecting microscope.

A variety of terms is used in describing Coelenterata. As far as possible, the terms used by Allman are retained. A tubularian colony is formed by several hydranths with a common coelenteron. A clump or cluster of hydranths is made up of several colonies often too densely entangled to permit separation. To standardize, the hydranths are described as mature or immature. An individual is considered mature when the gonophores contain spermatozoa or developing ova.

\section{SPECIFIC CHARACTERS}

Allman's description of $T$. larynx can be summarized as follows.

\section{Trophosome}

Hydrocaulus, numerous branching stems with more or less distinctly marked transverse annulations, $3.5-5.0 \mathrm{~cm}$ or more in length.

Coenosarc forming a collar-like expansion below the hydranth. In describing $T$. polycarpa Allman states that it has a fluted collar, as found in $T$. larynx.

Hydranth, I4-20 distal (oral) tentacles in two closely approximate alternate series, with about 20 proximal (aboral) tentacles each about $\mathrm{I} \mathrm{cm}$ long. The hydranth is $0.5 \mathrm{~cm}$ wide across the widest part of the body.

\section{Gonosome}

Gonophores in long, pendulous clusters; in the male long simple racemes, longer than the aboral tentacles. In the female they are shorter and the peduncle (blastotyle) is branched to form a panicle or compound raceme. The male gonophore is elongated, the female globular oval in form.

Apical processes, four conical ones, larger in the female than in the male.

Radiating canals: no gastro-vascular canals.

\section{Actinula}

No oral tentacles at the time of liberation. 


\section{OBSERVATIONS}

As will be shown, few of these characters are stable. Many of them have been found to vary according to the size of the hydranth, and this depends on age and stage of development.

For recognition purposes it has been found necessary to concentrate on 'mature' characters, ignoring 'immature'. Though Tubularia larynx forms a colony of individual hydranths with a common coelenteron, these are never all the same age. The age differences are accentuated by the phenomena of autotomy and regeneration. In most colonies, however, some of the hydranths will be mature.

\section{Trophosome}

Hydrocaulus. Branching has been found to be of universal occurrence and is frequent during early stages of colony formation when the stolon of the newly settled actinula grows along the substrate, forming the hydrorhiza. False branches are formed by actinulae growing on the parent stems. These are very prevalent in some colonies and the false are difficult to distinguish from true branches.

The length of the stem is very variable and has no bearing on the maturity of the hydranth, because of autotomy and regeneration. Colonies have been examined with stems varying from $\mathrm{I} \cdot 2$ to $17 \cdot 0 \mathrm{~cm}$ in length. Environmental factors such as salinity and current force may affect growth in length. D'Arcy Thompson (I942) mentions experiments by Loeb (1906), which showed that stems regenerating in hypotonic sea water were larger than those in hypertonic or normal; the maximum increase was in $2.2 \%$ sea water. It was noticed that the longest colonies were taken from a raft which swung in response to the tidal currents: these colonies were unable to support the hydranths when placed in a jar, so weak were the stems. The weakness may be due to a thin perisarc secreted during a period of a fast growth brought about by factors other than current.

The factors affecting growth in length will also influence the occurrence of annulations in the perisarc. Berrill $(1952 b)$ has suggested that these represent surges in growth in $T$. crocea similar to those in other gymnoblastic hydroids described by him (Berrill, I949a, $b$; 1952a) and by Hauschka (I944).

However, the rhythmic growth pulsations they record have never been seen in $T$. larynx, so this is not an adequate explanation for this species.

Growth in T. larynx occurs both at the stolon tip and in the stem below the hydranth, and it is in these areas that the annulations are formed. These areas are linked by the hydroplasmic tension in the coelenteron. Hydroplasmic pressure is defined by Hauschka (I944) as 'pressure over and above internal resistance of static form to compression from without'. The existence of such a pressure can be shown by cutting the stem below the growth region. The 
diameter of the growth region will be immediately reduced, showing that it has been under a pressure from within and that the thin perisarc is still flexible and unable to withstand compression from without; the stolon apex is similar in this respect.

The annulations are formed in these zones whilst the chitin is still malleable. Observations suggest that they are formed mechanically through the agency of the hydroplasmic tension. This force is stable throughout the length of the coelenteron, so an increase of pressure at any point will be transmitted throughout the coelenteron. Pressure is increased by the nutritive movements of the hydranth.

These movements appear co-ordinated and have been analysed as three cycles. First, the aboral tentacles are raised vertically, the hypostome contracts and its base swells, dilating the peristome and manubria of the gonophores. This circulates the fluids within the hydranth; the manubria expand and contract once or twice independently. The hypostome relaxes and lengthens, peristaltic waves move up and down its length, circulating nutritive fluids. Finally, the whole hydranth is pulled down on the stem by contraction of the growing region, apparently by longitudinal muscles. This last movement is occasionally preceded by the opening of the gland dividing the stomach from the coelenteron, resulting in the exchange of fluids between them. The movement itself will result in increased hydroplasmic pressure at the stolon, distending it. This could be called a 'growth surge', but it is not produced by regular pulsations of the coenosarc as are the pulsations described by Berrill and Hauschka. Furthermore, when there are several hydranths with a common coelenteron their movements being unco-ordinated will produce varying pressures at the stolon apex. After the autotomy of a hydranth of a colony the hydroplasmic pressure induced by the others will be applied to the area of regeneration, possibly resulting in a reduction of stolonic growth.

Each distension at the stolon apex is limited in circumference by the chitin secreted by the coenosarcal ectodermis. The hardening of the chitin posterior to the apex results in the formation of annulations, marking each successive distension or 'growth surge' of the apex. The annulations are less regular and are often incomplete in the growth region below the hydranth where the downward movement of the hydranth results in a concertina-like in-folding of the coenosarc (Fig. I). A series of contractions will result in the formation of an annula by the hardening of the perisarc. Further annulae will be formed as growth takes place; their irregularity being due to variations in growth rate as well as to environmental factors which may influence the angle of growth. The length of the region of growth, where the perisarc is still pliable, will be limited mechanically by the ability of the coenosarc aided by hydroplasmic tension to support the hydranth erect-these are constant factors-as well as by any environmental factors which aid or hinder growth. The inter-relationship of these influences will be secondarily reflected in the frequency and size 
of the annulae. A slow-growing colony might then be expected to have a thickened well-annulated perisarc, whereas a fast-growing one would have a thinner and so less clearly annulated perisarc.

No colony examined during the period of this study has been entirely devoid of annulations.

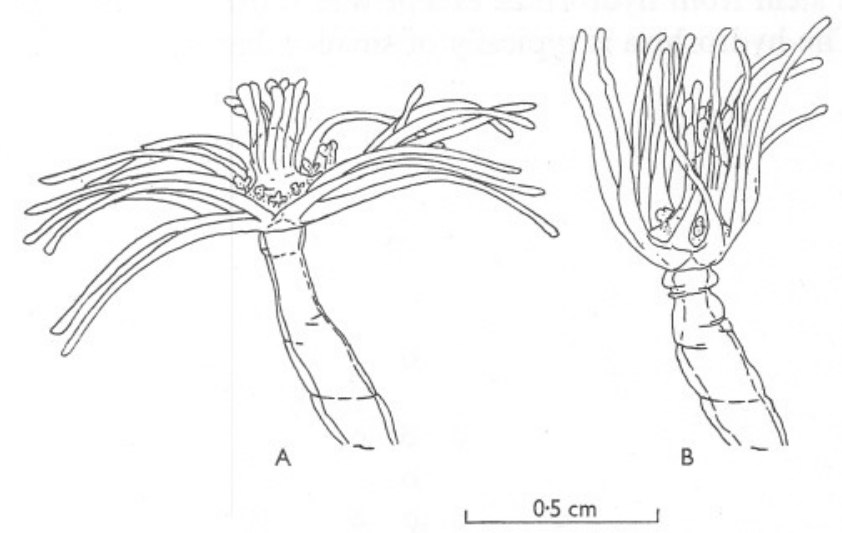

Fig. I. A, immature hydranth with aboral tentacles extended horizontally. B, same, on completion of the third cycle of the nutritive movements-aboral tentacles vertical, peristome dilated and the growth region contracted folding the perisarc into annulae. (Drawn by camera lucida.)

\section{Coenosarc}

The coenosarc is said by Allman to form a collar below the hydranth similar to $T$. polycarpa.

This collar expands and contracts independently of the nutritive movements described previously. Beutler (1926) described these contractions as connected with the circulation of nutritive fluids within the coelenteron. Her diagrams are reproduced in Borradaile, Potts, Eastham \& Saunders (1948). These contractions have been seen more frequently in the mature ageing polyp which has ceased to grow in length; the perisarc is stiff right to the base of the hydranth which is thus restricted in its movements. Such individuals are thought to be ageing because the clusters of gonophores on the peristome appear to prevent the aboral tentacles from rising to the vertical. The collar itself increases in circumference with the growth of the hydranth and there is little doubt that this increase is reflected in the increasing circumference of the perisarc of the stem, as compared with that of the hydrorhizal area.

It is difficult to decide whether this collar is itself a specialized organ or merely a dilation differentiated mechanically by the nutritive movements and the stomach contractions. The latter is the more probable explanation. It is recognized first some days after the settled actinula has started to feed and it increases in conformity with the width of the hydranth. 
The fluting is formed by chitin secreted by the ectoderm and furrowed by the muscle movements of the collar.

\section{Hydrorhiza}

Allman gives no specific characters for the hydrorhiza. It is difficult to differentiate stem from hydrorhiza except where the latter is attached to the substrate. The hydrorhiza is typically of smaller diameter than the stem.

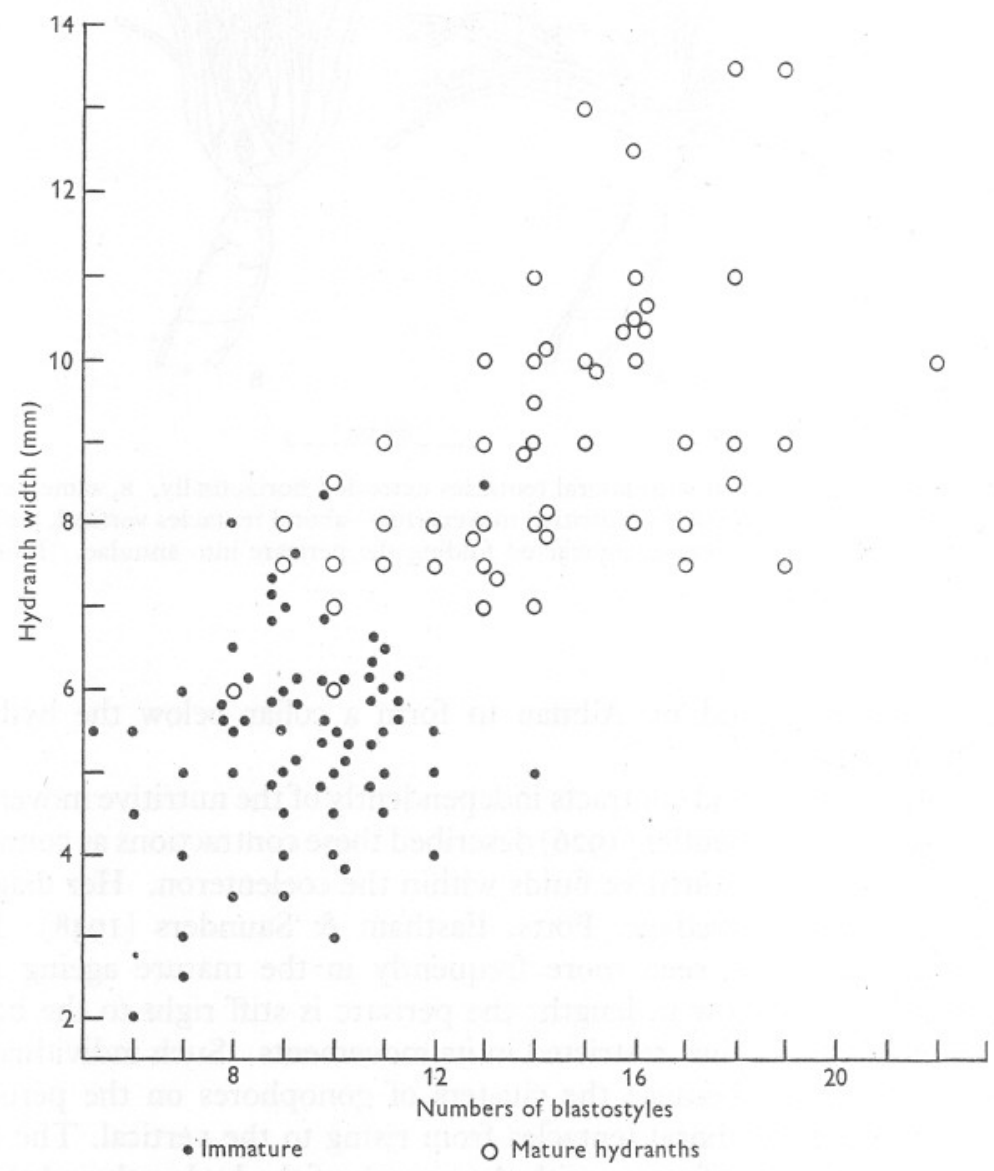

Fig. 2. Scatter diagram illustrating the correlation between the numbers of blastostyles and the widths of the hydranths. (Data in Appendix A.)

\section{Hydranth}

In describing the hydranth Allman describes his species as being of definite widths or having definite numbers of tentacles. The reliance given by other workers to these figures has resulted in the erection of invalid species.

Examination of many clusters showed these characters to be very variable. 
A clump of $\mathrm{I} 20$ hydranths was then examined in detail. All individuals with gonophores, whether mature or not, were examined and the numbers of tentacles and gonophores, the sex and the widths of the hydranths were recorded (Appendix A). There is an intercorrelation between width, numbers of blastotyles and numbers of aboral tentacles. Figs. 2 and 3 show this, demonstrating that an increase in hydranth size is accompanied by increases in numbers of tentacles and blastostyles, which is to be expected. Any identification based on such characters must allow for this correlated increase.

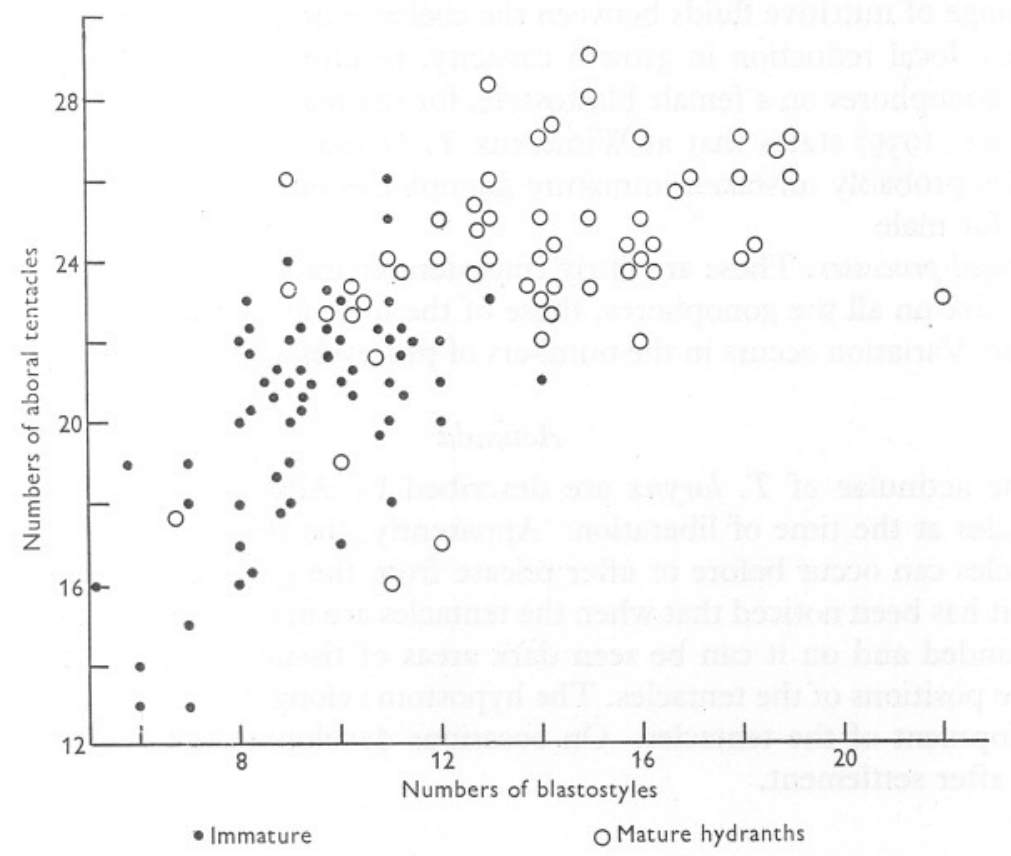

Fig. 3. Scatter diagram showing the correlation between the numbers of blastostyles and of aboral tentacles. (Data in Appendix A.)

\section{Gonosome}

Gonophores. In general, the mature male gonophores are smaller than the mature female; they are oval whereas the female are round. Moreover, the developing ovum displaces the manubrium within the gonophore. A male hydranth appears whiter because of the dense white spermatozoa and spermatocytes within the gonophore, mature and immature being distinguished from each other by size. Immature males and females are frequently indistinguishable.

Hermaphrodites have been found. The apical gonophores of a mature and ageing female hydranth are frequently male.

Liu \& Berrill (I948) and Berrill (I952b) have recorded hermaphrodites in T. crocea. Berrill also terms such colonies as ageing. He suggests that male 
gonophores are budded on a female blastostyle as the result of a reduction in growth capacity; a maximum growth rate being necessary for the initiation of the large female gonad. When this is not attained male gonophores develop in place of female.

In support of this suggestion is the observation made earlier that such individuals are considered aged because the nutritive movements of the hydranth are restricted by the numbers of blastostyles and gonophores on the peristome. The hardening of the perisarc below the hydranth reduces the exchange of nutritive fluids between the coelenteron and hydranth. This may cause a local reduction in growth capacity, resulting in the development of male gonophores on a female blastostyle, for the reasons suggested by Berrill.

Pérez (1939) states that at Wiméreux T. larynx is always hermaphrodite. He has probably mistaken immature gonophores on a mature female blastostyle for male.

Apical processes. These are fairly consistent characters. They are not of the same size on all the gonophores, those of the male are often smaller than the female. Variation occurs in the numbers of processes as well as in their length.

\section{Actinula}

The actinulae of T. larynx are described by Allman as not having oral tentacles at the time of liberation. Apparently, the development of the oral tentacles can occur before or after release from the gonophore. At the same time it has been noticed that when the tentacles are not formed the hypostome is rounded and on it can be seen dark areas of tissue approximating to the future positions of the tentacles. The hypostome elongates at the same time as development of the tentacles. On occasions development has been delayed until after settlement.

\section{Material Collected in Plymouth Sound}

The material to be described can be divided into that collected from a raft near the Breakwater, over a period of several weeks, and that collected from various buoys, etc., in other parts of the Sound. Mature specimens were found at all times between June and late September, though they became scarce in August, when clumps without hydranths were frequently found.

\section{Trophosome}

Hydrocaulus. Length $\mathrm{I} \cdot 5-17.5 \mathrm{~cm}$. It was noticed that the perisarc of the longer stems- $10 \mathrm{~cm}$ and more-was soft and thin in contrast with that of smaller individuals. The longest stems were those of a clump growing attached to a piece of twine trailing from the raft. In general, the material from the raft was of a greater length than elsewhere. 
Regular annulations were common and more pronounced in the shorter stems, in which branching was more frequent. It is suggested that in the longer colonies collected from the raft where the current was persistent the actinulae were released and swept away from the parent hydranth. In colonies where the current direction varied, some actinulae are trapped amongst the parent stems to which they become attached, increasing the amount of apparent or false branching.

Ceonosarc. A collar occurs beneath the hydranth and it increases in size with age. It appears to be fluted in ageing individuals for reasons given earlier.

Hydrorhiza. Branching and annulations are frequent. This zone is smaller in circumference than the stem.

Hydranth. The numbers of tentacles show great variation; an increase in circumference of the oral cone and the peristome is accompanied by an increase in the numbers of tentacles. Examples of the amount of variation that occurs in mature individuals is recorded in Appendix B.

\section{Gonosome}

Gonophores. Blastostyles occur in one or two rows on the peristome; the number of rows increases according to the size of the hydranth. In the sample (Appendix A) the blastostyles vary from 5 to 22. The gonophores are occasionally pendulous; up to 35 have been counted on a single blastostyle.

Apical processes. Usually four in both sexes-occasionally less-easily distinguished in the female but seldom of equal size.

\section{Actinula}

Oral tentacles are usually developed prior to liberation from the gonophore. Numbers of aboral tentacles have varied between 7 and II, and oral between 3 and 5 .

\section{Discussion}

Brink (I925a) remarked that '.. the weak point of hydroid systematics is due to the fact that the study of the variability of external features has not kept pace with the discovery of new species'. He drew attention to Fenchel's (I905) examination of the literature, which demonstrated this point. Many new species have been described since.

There is no doubt that the material described here constitutes a single species. Sufficient variation can be found within a large clump to cover many of the species described by Allman. For instance, T. bellis differs from larynx only in the height of the colony described. Similarly, in T. humilis he describes the 'male'; the small number of gonophores suggests that Allman was describing an immature, recently regenerated hydranth. A similar error could have been made in the species $T$. attenuata. $T$. polycarpa owes its creation to having been found on the bottom of a ship in Coquimbo harbour. 


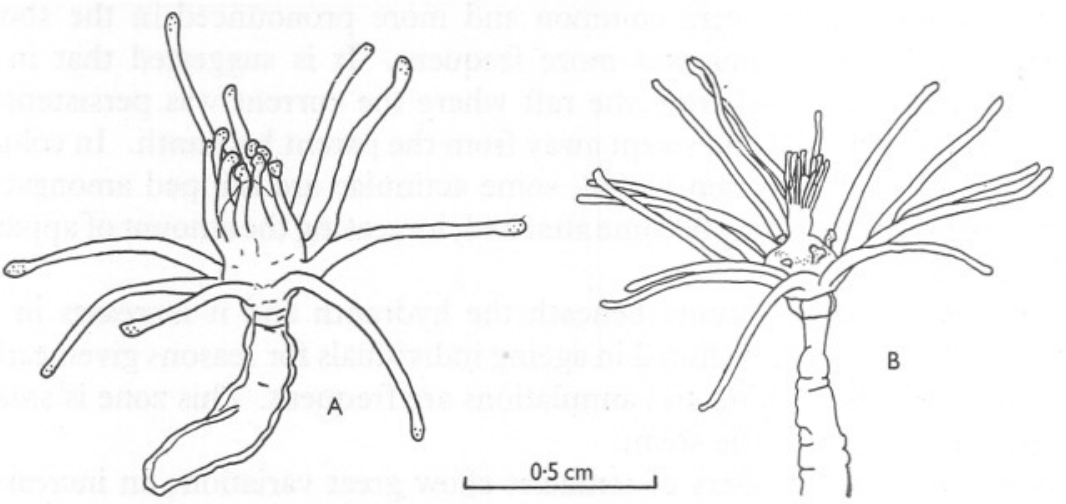

Fig. 4. A, a recently settled actinula drawn by camera lucida. Compare with Hincks, Vorticlava, Vol. I, p. 132, and Vol. 2, pl. XXIII. B, an immature regenerated hydranth. Compare with Hincks, Vol. 2, pl. XXIII. (Drawn by camera lucida.)

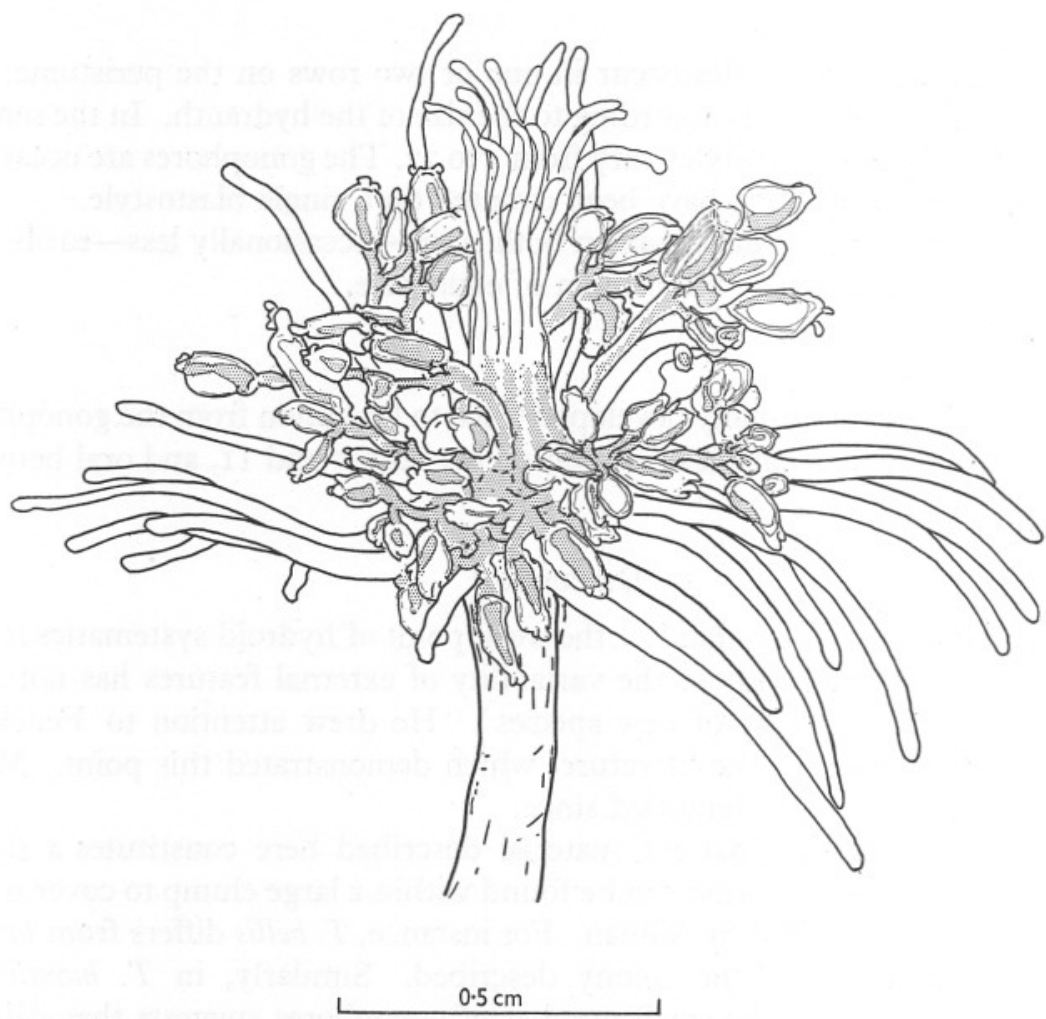

Fig. 5. Mature female hydranth showing the displacement of the manubria, within the gonophores, by the developing ova and actinula. (Drawn by camera lucida.) 
Brink ( $\left.1925^{b}\right)$ considered the species of Vorticlava and Acharadria to be stages in the development of T. larynx. From Alder's description Vorticlava is certainly a newly settled actinula, as suspected by Hincks. Wright's drawing of Acharadria, however, resembles more closely an immature, regenerating hydranth, rather than a stage in the growth of a colony, because of the large number of tentacles and simultaneous absence of gonophores.

It is not possible to describe accurately the geographic distribution of $T$. larynx. It is certainly found in all oceans but it is, as yet, recorded under many different specific names.

It must be emphasized that Allman's specific characters are valid when full allowance is made for the diversity that occurs in the species. This is reduced when several mature individuals are used in identification.

\section{SUMMARY}

As certain previous authors have observed, T. larynx is a species subject to much variation. Disregard of this has led to the erection of invalid species.

The descriptive characters used by Allman are discussed. In a comparison with material collected in Plymouth Sound these characters are shown to be so variable that used singly they are valueless. In particular, disregard of the stage of development and over-emphasis on size will be very misleading.

The causes of some of this variability are suggested.

\section{REFERENCES}

Allman, G. J., 1871-72. A monograph of the Gymnoblastic or Tubularian Hydroids. Parts I and II. London.

BerriL, N. J., I949a. Polymorphic transformations of Obelia. Quart. F. micr. Sci., Vol. 90, pp. 235-64.

- I949b. Growth and form in gymnoblastic hydroids. I. Polymorphic development in Bougainvillia and Aselomaris. F. Morph., Vol. 84, pp. I-30.

- I952a. Growth and form in gymnoblastic hydroids. II, III, IV. Rathkea, Pennaria, Acaulis and Eudendrium. F. Morph., Vol. 90, pp. I-32.

- I952b. Growth and form in gymnoblastic hydroids. V. Growth cycle in Tubularia. F. Morph., Vol. 90, pp. 583-601.

BeUtLER, R., I926. Beobachtungen an gefütterten Hydroidpolypen. Z. vergl. Physiol., Bd. 3, pp. 737-75.

Borradaile, L. A., Potts, F. A., Eastham, L. E. S. \& Saunders, J. T., I948. The Invertebrata. Second Edition. Cambridge University Press.

BRINK, R., I925 $a$. Notes concerning the variability and the action of environmental influences on the structure and growth of the hydroid colony Bougainvillia ramosa (v. Ben.) Lesson, and its bearing on systematics. Proc. Acad. Sci. Amst., Vol. 27, pp. 9-IO.

— I $925 b$. Beiträge zur Herstellung einer rationellen Hydroiden-systematic. II. Über Entwicklungstadien von Tubularia larynx Ell. e Sol. und deren Variations-erscheinungen. Tijdschr. ned. dierk. Ver., Ser. 2, Deel I9, pp. 167-205.

Fenchel, A., I905. Über Tubularia larynx Ellis. Rev. Suisse Zool., T. I3, pp. 507-80.

HARgitt, C. W., I927. Some hydroids of South China. Bull. Mus. comp. Zool. Harvard, U.S., Vol. 67, pp. 489-520. 
Hauschka, T. S., I944. Rôle of hydroplasmic pressure in hydroid growth. Growth, Vol. 8, pp. 32I-36.

Hincks, T., I868. A History of the British Hydroid Zoophytes. Vols. I and II. London: John Van Voorst.

LiU, C. K. \& BerRILL, N. J., I948. Development of the gonophore in Tubularia. f. Morph., Vol. 83, pp. 39-60.

Loeb, J., I906. Studies in General Physiology. Part I. Chicago: University of Chicago Press.

PÉREZ, C., I920. Notes sur la Faune marine du Boulonnais. II. Tubularia ceratogyne n.sp. Bul. Soc. zool. Fr., T. 45, pp. I7I-7.

- 1925. Variations et anomalies chez les Tubulaires. C.R. Ass. franç. Av. Sci., T. 44, pp. 318-19.

- 1939. Quelques anomalies observées chez les hydraires gymnoblastiques. Trav. Sta. zool. Wiméreux, T. 13, pp. 539-44.

PyeFinch, K. A. \& Downing, F. S., I949. Notes on the general biology of Tubularia larynx Ellis \& Solander. F. Mar. biol. Ass. U.K., Vol. 28, pp. 2I-43.

SteChow, E., I925a. Hydroiden der Deutschen Tiefsee-Expedition. Wiss. Ergebn. 'Valdivia', Bd. I7, pp. 383-546.

- I925b. Hydroiden von West und Sudwestaustralien nach den Sammlungen von Prof. Dr Michaelsen und Prof Dr Hartmeyer. Zool. Fb., Bd. 50, pp. I9I-269.

ThOMPSON, D'ARCY W., I942. Growth and Form. Cambridge University Press.

UchIDA, T., 1936. A new hydroid T. radiata n.sp. from Akkeshi. Annot zool. jap., Vol. I6, pp. 157-8.

Vervoort, W., 1946. Hydroiden uit de Waddenzee. Arch. néerl. Zool., Vol. 7, pp. 334-52.

YAMADA, M., 1950. Fauna of Akkeshi Bay. XVIII. Hydroids. F. Fac. Sci. Hokkaido Univ., Ser 6 (Zool.), Vol. Io. pp. I-20.

\section{APPENDIX A}

\section{Data ObTained from Examining a Clump of TUBUlaria LAR YNX Collected on a Buoy near Remains of the Pier}

(The graphs are drawn from these data. $M=$ mature; $I=$ immature.)

\begin{tabular}{|c|c|c|c|c|c|c|c|}
\hline \multirow[b]{2}{*}{ Sex } & & \multirow{2}{*}{$\begin{array}{l}\text { Hydranth } \\
\text { width } \\
\text { (mm) }\end{array}$} & \multirow{2}{*}{$\begin{array}{l}\text { Length } \\
\text { aboral } \\
\text { tentacles } \\
(\mathrm{mm})\end{array}$} & \multicolumn{2}{|c|}{ Nos. tentacles } & \multicolumn{2}{|c|}{ Blastostyles } \\
\hline & & & & Oral & Aboral & Nos. & Rows \\
\hline 웅 & $M$ & $7 \cdot 5$ & - & $\begin{array}{l}22 \\
20\end{array}$ & $\begin{array}{r}27 \\
24\end{array}$ & $\begin{array}{l}19 \\
16\end{array}$ & $\begin{array}{l}2 \\
2\end{array}$ \\
\hline to & M & $\begin{array}{l}10.3 \\
10.0\end{array}$ & - & $2 \mathrm{I}$ & $\begin{array}{l}24 \\
27\end{array}$ & 16 & 2 \\
\hline 4 & $\mathrm{M}$ & 8.0 & - & I7 & 22 & I4 & I \\
\hline$\Phi$ & $\mathrm{M}$ & 10.0 & - & $2 \mathrm{I}$ & 26 & 13 & 2 \\
\hline 우 & M & 10.0 & - & 22 & 23 & 22 & 2 \\
\hline 7 & M & 10.0 & - & 20 & 29 & 15 & 2 \\
\hline 7 & M & II $\cdot 0$ & - & 22 & 24 & I8 & 2 \\
\hline 0 & M & I 2.5 & - & 23 & 24 & I6 & 2 \\
\hline q & M & 8.0 & - & I9 & 28 & 13 & 2 \\
\hline+ & M & 10.5 & $\because$ & 22 & 24 & I6 & 2 \\
\hline 우 & M & 9.0 & - & 20 & 26 & I9 & 2 \\
\hline & M & $7 \cdot 0$ & - & I6 & 23 & IO & I \\
\hline & M & 6.0 & - & I8 & 22 & 8 & I \\
\hline
\end{tabular}


APPENDIX A (continued)

\begin{tabular}{|c|c|c|c|c|c|c|c|}
\hline \multirow[b]{2}{*}{ Sex } & & \multirow{2}{*}{$\begin{array}{l}\text { Hydranth } \\
\text { width } \\
(\mathrm{mm})\end{array}$} & \multirow{2}{*}{$\begin{array}{l}\text { Length } \\
\text { aboral } \\
\text { tentacles } \\
(\mathrm{mm} .)\end{array}$} & \multicolumn{2}{|c|}{ Nos. tentacles } & \multicolumn{2}{|c|}{ Blastostyles } \\
\hline & & & & Oral & Aboral & Nos. & Rows \\
\hline 오 & $M$ & 7.5 & - & 21 & 26 & 17 & I \\
\hline o & M & 8.0 & - & 20 & 26 & 9 & I \\
\hline † & M & 8.5 & - & 23 & 26 & I8 & 2 \\
\hline 우 & M & $8 \cdot 0$ & - & $2 \mathrm{I}$ & 24 & I2 & I \\
\hline 우 & M & $8 \cdot 5$ & - & 20 & 23 & IO & I \\
\hline 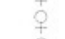 & $M$ & II $\cdot 0$ & - & 20 & 24 & I6 & 2 \\
\hline of & $M$ & 13.0 & 5.0 & I9 & 25 & 15 & 2 \\
\hline † & $M$ & 8.0 & 3.0 & 20 & I7 & I2 & I \\
\hline 우 & M & II $\cdot 0$ & - & 23 & 25 & 14 & 2 \\
\hline † & M & 9.5 & 3.0 & I8 & 27 & I4 & 2 \\
\hline † & M & 8.0 & - & 22 & 27 & I4 & 2 \\
\hline 우 & M & 8.0 & 3.5 & $2 \mathrm{I}$ & 25 & I3 & 2 \\
\hline + & M & 7.5 & 3.0 & I6 & 23 & 9 & I \\
\hline 9 & $M$ & 7.5 & $2 \cdot 5$ & I9 & 25 & I2 & I \\
\hline 후 & M & $9 \cdot 0$ & & I9 & 27 & 18 & 2 \\
\hline 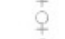 & M & 7.0 & 3.0 & I9 & $2 \mathrm{I}$ & 9 & I \\
\hline+ & M & I0.0 & 3.7 & 23 & 23 & I4 & 2 \\
\hline$\hat{o}$ & M & 6.0 & 2.5 & I8 & 23 & IO & $\mathrm{I}$ \\
\hline q & $M$ & 10.0 & 3.7 & I9 & 23 & I4 & 2 \\
\hline † & $M$ & 8.0 & 3.0 & $2 \mathrm{I}$ & 22 & 16 & 2 \\
\hline 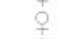 & M & 9.0 & $\begin{array}{l}3.0 \\
3.0\end{array}$ & 18 & 22 & II & I \\
\hline + & M & 13.5 & 5.0 & 24 & 24 & 18 & 2 \\
\hline 우 & $M$ & 6.0 & $2 \cdot 0$ & 19 & 22 & 9 & I \\
\hline 우 & M & 8.0 & 3.5 & 22 & 24 & II & 2 \\
\hline 우 & $M$ & 13.5 & 5.0 & I9 & 27 & 19 & 2 \\
\hline 우 & M & 10.0 & 3.5 & 23 & 28 & 15 & I \\
\hline+ & M & $9 \cdot 0$ & 3.0 & 24 & 25 & I3 & - \\
\hline 후 & M & $9 \cdot 0$ & 3.5 & 18 & 23 & 14 & 2 \\
\hline 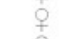 & M & 10.5 & 3.7 & $2 \mathrm{I}$ & 25 & 16 & 2 \\
\hline 우 & $M$ & $7 \cdot 5$ & 3.0 & $2 \mathrm{I}$ & 23 & IO & I \\
\hline 우 & M & 9.0 & 3.5 & 25 & 26 & I 7 & 2 \\
\hline+ & M & 10.5 & $4 \cdot 5$ & 22 & 24 & I6 & 2 \\
\hline 우 & M & $9 \cdot 0$ & 3.5 & 22 & 24 & I4 & I \\
\hline † & $M$ & 7.0 & 3.0 & 22 & 24 & 13 & I \\
\hline 우 & $M$ & 7.5 & 3.0 & I9 & 25 & I3 & I \\
\hline + & M & 8.0 & $\begin{array}{l}0.0 \\
3.0\end{array}$ & - & 24 & I4 & I \\
\hline \$ & M & $7 \cdot 0$ & 3.0 & 23 & 23 & I4 & I \\
\hline †े & M & 9.0 & 3.5 & 20 & 23 & 15 & I \\
\hline ㅇ & $M$ & 5.0 & 2.0 & I2 & 16 & II & I \\
\hline 우 & $M$ & $7 \cdot 5$ & 3.0 & 18 & 24 & II & I \\
\hline iq & I & 5.5 & - & 20 & 20 & I2 & I \\
\hline + & I & $7 \cdot 0$ & - & 26 & 23 & IO & I \\
\hline 우 & $\vec{I}$ & 8.5 & $3 \cdot 0$ & 23 & 23 & 13 & I \\
\hline 우 & $\bar{I}$ & 8.5 & 3.5 & 18 & 22 & IO & I \\
\hline of & $\hat{I}$ & 6.0 & 35 & I4 & 22 & II & I \\
\hline i & I & 7.5 & 2.5 & 18 & 24 & 9 & I \\
\hline$\hat{0}$ & $\overline{\mathrm{I}}$ & 6.0 & 2.5 & 18 & 23 & I0 & I \\
\hline to & I & $6 \cdot 0$ & 2.5 & 20 & 22 & II & I \\
\hline 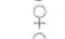 & I & $6 \cdot 0$ & $2 \cdot 2$ & I4 & $2 \mathrm{I}$ & 9 & I \\
\hline 守 & I & $7 \cdot 5$ & $3 \cdot 2$ & 16 & $2 \mathrm{I}$ & 9 & I \\
\hline- & $\vec{I}$ & 7.0 & 2.5 & I8 & $2 \mathrm{I}$ & 9 & I \\
\hline- & $\bar{I}$ & 6.0 & 2.0 & I9 & 22 & 9 & I \\
\hline- & I & $6 \cdot 0$ & 2.5 & 22 & I8 & 7 & I \\
\hline- & I & 8.0 & 3.5 & I9 & 23 & 8 & I \\
\hline - & I & 4.0 & $\mathrm{I} \cdot 5$ & 19 & $2 \mathrm{I}$ & IO & I \\
\hline- & $\bar{I}$ & 7.0 & 3.0 & 15 & 19 & 9 & I \\
\hline- & I & 5.5 & $2 \cdot 2$ & 19 & 22 & I0 & I \\
\hline- & I & $5 \cdot 5$ & 2.0 & 15 & 16 & 5 & I \\
\hline - & I & $2 \cdot 5$ & 0.75 & - & I5 & 7 & I \\
\hline - & I & $2 \cdot 0$ & 0.75 & I6 & I3 & 6 & I \\
\hline- & I & 6.0 & 2.5 & I7 & 16 & 8 & I \\
\hline- & I & 3.0 & $I \cdot 2$ & I4 & I7 & IO & I \\
\hline - & I & 5.0 & - & 20 & $2 \mathrm{I}$ & IO & I \\
\hline 23 & & & & & RN. MAR & ssoc & I955 \\
\hline
\end{tabular}




\begin{tabular}{|c|c|c|c|c|c|c|c|}
\hline & & & PENDIX & ontin & & & \\
\hline & & Hydranth & Length & Nos. & tacles & Bla & yles \\
\hline Sex & & $(\mathrm{mm})$ & (mm.) & Oral & Aboral & Nos. & Rows \\
\hline - & I & 5.0 & - & 19 & $2 I$ & II & I \\
\hline - & I & 5.0 & - & 16 & $2 \mathrm{I}$ & 9 & I \\
\hline - & I & 5.5 & - & 19 & 20 & II & I \\
\hline - & I & 3.5 & - & Io & I6 & 8 & I \\
\hline - & I & 5.0 & - & 20 & 22 & $\mathrm{I} 2$ & I \\
\hline$\hat{0}$ & I & 6.0 & 2.5 & $2 I$ & $2 I$ & 9 & I \\
\hline$\hat{0}$ & I & $6 \cdot 0$ & $2 \cdot 5$ & 17 & 22 & IO & I \\
\hline$\hat{\sigma}$ & I & 4.5 & $\mathrm{I} \cdot 7$ & I4 & 20 & IO & I \\
\hline 웅 & $\overline{\mathrm{I}}$ & 6.5 & $2 \cdot 7$ & $2 \mathrm{I}$ & 22 & II & I \\
\hline ó & I & $5 \cdot 5$ & $2 \cdot 2$ & I6 & 20 & 8 & I \\
\hline 움 & I & 5.5 & 2.5 & I8 & I4 & 6 & I \\
\hline 움 & $\mathrm{I}$ & 4.0 & $I \cdot 5$ & I8 & I9 & 7 & I \\
\hline 우 & I & 5.5 & $2 \cdot 2$ & I9 & 20 & IO & I \\
\hline + & $\mathrm{I}$ & 6.5 & $2 \cdot 7$ & 16 & 22 & 8 & I \\
\hline ㅇ & I & $5 \cdot 5$ & $\mathrm{I} \cdot 5$ & I5 & 20 & II & I \\
\hline- & I & 5.0 & $2 \cdot 0$ & 22 & I9 & IO & I \\
\hline - & I & 5.5 & $2 \cdot 2$ & I5 & $2 I$ & IO & I \\
\hline- & I & 5.0 & 2.0 & I8 & 22 & 8 & I \\
\hline - & $I_{1}$ & 6.0 & $2 \cdot 5$ & 17 & 22 & 9 & I \\
\hline - & I & 5.5 & $2 \cdot 2$ & 18 & 22 & II & I \\
\hline - & I & 3.5 & $\mathrm{I} \cdot 2$ & I6 & I8 & 9 & I \\
\hline- & I & 5.5 & $2 \cdot 2$ & 19 & 20 & 8 & I \\
\hline- & I & 5.5 & $2 \cdot 2$ & 22 & I9 & IO & I \\
\hline - & I & 6.0 & 2.5 & I5 & 22 & II & I \\
\hline - & I & 4.0 & $I \cdot 5$ & I4 & I8 & IO & I \\
\hline- & I & 6.0 & 2.5 & I8 & $2 \mathrm{I}$ & II & I \\
\hline- & I & 4.0 & $\mathrm{I} \cdot 5$ & 17 & $2 I$ & I 2 & I \\
\hline- & I & 6.5 & $2 \cdot 7$ & 20 & 23 & II & I \\
\hline- & I & $5 \cdot 5$ & $2 \cdot 2$ & $2 \mathrm{I}$ & 17 & 8 & I \\
\hline- & I & 5.0 & 2.0 & I9 & $2 \mathrm{I}$ & I4 & - \\
\hline- & I & 6.0 & 2.5 & I9 & 26 & II & - \\
\hline- & I & 4.0 & $\mathrm{I} \cdot 5$ & I5 & I9 & 9 & I \\
\hline- & I & 5.0 & 2.0 & 18 & 19 & IO & I \\
\hline- & I & 5.0 & 2.0 & I8 & I8 & 9 & I \\
\hline- & I & 6.0 & $2 \cdot 2$ & I6 & I8 & 8 & I \\
\hline- & I & 4.5 & $\mathrm{I} \cdot 7$ & I7 & $2 I$ & 9 & I \\
\hline- & I & $6 \cdot 5$ & $2 \cdot 7$ & $2 \mathrm{I}$ & 25 & II & I \\
\hline- & I & $4 \cdot 5$ & $I \cdot 7$ & I4 & 19 & 6 & I \\
\hline- & I & 4.5 & $\mathrm{I} \cdot 7$ & 17 & 18 & II & I \\
\hline- & I & 3.0 & $\mathrm{I} \cdot 2$ & I5 & I3 & 7 & I \\
\hline- & I & 5.0 & $2 \cdot 0$ & I4 & I8 & 7 & I \\
\hline- & I & 5.0 & - & 20 & $2 I$ & IO & I \\
\hline- & I & 5.0 & - & I9 & $2 I$ & II & I \\
\hline
\end{tabular}

\section{APPENDIX B}

Records of Clump Heights and Tentacle Numbers of Mature INDIVIDUALS IN Clumps COLLECTED IN VARIOUS

Parts of Plymouth Sound

\begin{tabular}{|c|c|c|c|c|}
\hline \multirow[b]{2}{*}{ Locality } & \multirow{2}{*}{$\begin{array}{l}\text { Clump height } \\
(\mathrm{cm} .)\end{array}$} & \multicolumn{2}{|c|}{ Variation in tentacle nos. } & \multirow{2}{*}{$\begin{array}{c}\text { No. } \\
\text { examined }\end{array}$} \\
\hline & & Oral & Aboral & \\
\hline Buoy chain, breakwater & $I \cdot 5-4 \cdot 0$ & $17-26$ & $18-25$ & I2 \\
\hline Buoy chain, Barn pool & $I \cdot 5-5 \cdot 0$ & I4 -37 & $13-35$ & 29 \\
\hline Buoy chain, Mount Batten & $I \cdot 5-5 \cdot 0$ & $17-22$ & I $8-25$ & 30 \\
\hline Raft, breakwater & $I \cdot 5-5 \cdot 0$ & I6-22 & $20-26 \mid$ & \\
\hline Raft, breakwater & $5 \cdot 0-7 \cdot 5$ & $2 I-3 I$ & $22-29$ & 90 \\
\hline Raft, breakwater & $7 \cdot 5-12 \cdot 5$ & $17-32$ & $19-32$ & \\
\hline Pier, buoy & $I \cdot 5-7 \cdot 0$ & I $2-24$ & I6-28 & 54 \\
\hline Total range of variation & $I \cdot 5-12 \cdot 5$ & I $2-37$ & I3-35 & 215 \\
\hline
\end{tabular}

